\title{
KOMODITAS PETERNAKAN UNGGULAN DI KABUPATEN CIAMIS
}

\section{POTENTIAL LIVESTOCK COMMODITIES IN CIAMIS DISTRICT}

\author{
Sri Mulyati*, Hj. Enok Sumarsih, Hj. Rina Nuryati \\ Jurusan Agribisnis, Fakultas Pertanian, Universitas Siliwangi, J1. Siliwangi No. 24 Tasikmalaya \\ *Email: sricms.1314@gmail.com
}

(Diterima 16-09-2020; Disetujui 29-12-2020)

\begin{abstract}
ABSTRAK
Era otonomi daerah memberikan kewenangan terhadap daerah untuk mengelola daerahnya sendiri termasuk pemanfaatan potensi daerah dalam melaksanakan pembangunan. Penelitian ini dilakukan dengan tujuan untuk mengidentifikasi komoditas peternakan yang menjadi basis di wilayah kecamatan di Kabupaten Ciamis, mengetahui pertumbuhan komoditas peternakan di wilayah kecamatan di Kabupaten Ciamis, dan mengidentifikasi komoditas peternakan yang menjadi unggulan di Kabupaten Ciamis. Penelitian dilaksanakan dari bulan Januari sampai September 2020. Metode penelitian yang digunakan adalah studi kasus terhadap tujuh komoditas peternakan yang dianalisis dengan SLQ dan DLQ serta Analisis Shift Share. Hasil penelitian menunjukkan: (1) Komoditas peternakan yang menjadi basis di wilayah kecamatan di Kabupaten Ciamis yaitu sapi, domba, kambing, ayam buras, ayam ras pedaging, ayam ras petelur, dan itik. (2) Pertumbuhan komoditas peternakan yang mengalami pertumbuhan yang cepat adalah sapi potong dan ayam ras petelur dan komoditas peternakan basis yang berdaya saing adalah sapi potong, domba, kambing, ayam buras, ayam ras pedaging, ayam ras petelur, dan itik. (3) Komoditas peternakan yang menjadi komoditas unggulan di Kabupaten Ciamis adalah sapi potong dan ayam ras petelur.
\end{abstract}

Kata Kunci: Komoditas Unggulan, Komoditas Peternakan, Static Location Quotient, Dynamic Location Quotient, Analisis Shift Share

\begin{abstract}
The era of regional autonomy gives authority to regions to manage their own regions, including the utilization of regional potentials in carrying out development. This research was conducted with the aim of identifying livestock commodities which are the base in the sub-district area in Ciamis Regency, knowing the growth of livestock commodities in the sub-district area in Ciamis Regency, and identifying livestock commodities which are the potential ones in Ciamis Regency. The research was conducted from January to September 2020. The research method used was a case study of seven livestock commodities analyzed by SLQ and DLQ and Shift Share analysis. The results showed: (1) The livestock commodities which are the base in the sub-district area in Ciamis Regency are cows, sheep, goats, native chickens, broilers, laying hens, and ducks. (2) The growth of livestock commodities that are experiencing rapid growth are beef cattle and layer and basic livestock commodities that are competitive are beef cattle, sheep, goats, domestic chickens, broilers, layer, and ducks. (3) Animal husbandry commodities which are the potential commodities in Ciamis Regency are beef cattle and layer.
\end{abstract}

Keywords: Potential Commodities, Animal Husbandry Commodities, Static Location Quotient, Dynamic Location Quotient, Shift Share Analysis

\section{PENDAHULUAN}

Sentralisasi pada era orde baru, membuat ketergantungan pemerintah daerah terhadap pusat sangat tinggi

sehingga tidak ada kemandirian

perencanaan pemerintah daerah saat itu. 
Akibat yang muncul dengan adanya sentralisasi pembangunan diantaranya: proses pembangunan daerah secara keseluruhan menjadi kurang efisien dan ketimpangan pembangunan antar daerah semakin besar. Kemudian menimbulkan ketidakadilan dalam alokasi sumberdaya nasional terutama dana pembangunan daerah. Era reformasi menjadi awal lahirnya kebijakan otonomi daerah, sesuai dengan UU No. 22 Tahun 1999 kemudian direvisi menjadi UU No. 32 Tahun 2004 tentang Pemerintah Daerah dan hingga saat ini direvisi kembali menjadi UU No. 23 Tahun 2014 tentang Pemerintah daerah. Di era otonomi daerah ini mengganti konsep pembangunan yang bersifat sentralisasi menjadi desentralisasi. Desentralisasi merupakan pelimpahan wewenang dari Pemerintah pusat ke daerah otonom untuk mengatur dan mengurus urusan pemerintahannya sendiri (Sjafrizal, 2014).

Adanya otonomi r daerah
memberikan kewenangan
pemerintah daerah untuk mengatur dan
mengurus urusan pemerintahan dan
kepentingan masyarakat setempat
menurut prakarsa sendiri berdasarkan
aspirasi masyarakat. Hal tersebut menjadi
pekerjaan rumah bagi pemerintah daerah

agar dapat memajukan daerahnya dan dapat bersaing dengan daerah otonom lainnya melalui upaya pembangunan daerah untuk meningkatkan kesejahteraan masyarakat. Sebagaimana diterangkan oleh Ruyadi (2002) dalam Yuda dan Navitas (2014) bahwa pembangunan daerah merupakan suatu upaya terpadu untuk memacu perkembangan sosial ekonomi, mengurangi kesenjangan antar daerah dan menjaga kelestarian lingkungan hidup pada suatu daerah.

Aspek-aspek yang memiliki potensi ekonomi di suatu daerah akan dikembangkan sebagai upaya dalam pembangunan daerah. Secara harfiah, potensi ekonomi dalam kerangka pembangunan daerah dapat diartikan sebagai kesanggupan kekuatan dan kemampuan di bidang ekonomi yang dimiliki oleh suatu daerah untuk membangun daerahnya masing-masing. Potensi ekonomi tersebut dapat berupa sumber daya alam, sumber daya manusia, letak geografis daerah yang dekat dengan sarana dan prasarana serta pendukung lainnya (Sudarti, 2009). Menurut Suyatno (2000), pembangunan daerah dapat diarahkan untuk memberdayakan potensi alam agar dapat lebih berdaya guna dan berhasil guna dalam meningkatkan hasil daerah. Selain itu, juga tiap-tiap wilayah 
perlu menentukan komoditas unggulan agar pembangunan daerah di masa yang akan datang dapat diarahkan pada pengembangan komoditas unggulan tersebut. Salah satu potensi alam yang melimpah di Indonesia adalah pertanian, sehingga pertanian merupakan bagian dari perekonomian nasional yang perlu untuk dikembangkan. Pengembangan komoditas pertanian harus disesuaikan dengan kondisi daerah setempat seperti kondisi agroklimat, sumber daya manusia, sarana dan prasarana yang ada, sehingga komoditas tersebut dapat menjadi komoditas unggulan daerah. Komoditas unggulan harus memiliki kontribusi yang besar terhadap pertumbuhan ekonomi suatu daerah.
Menurut Sjafrizal

(2014), pertumbuhan ekonomi suatu daerah dapat dilihat melalui peningkatan dari nilai Produk Domestik Regional Bruto (PDRB) daerah bersangkutan atau dengan menghitung nilai produksi dari tiap-tiap sektor dan sub sektor yang ada di daerah yang bersangkutan. Selain mengetahui pertumbuhan dari sektor dan subsektor dengan melihat PDRB atau menghitung nilai produksi tiap sektor dapat diketahui peranan sektor dan sub sektor tersebut dalam pertumbuhan ekonomi daerah. Struktur perekonomian Kabupaten Ciamis selama lima tahun terakhir (2014-2018) di Kabupaten Ciamis didominasi oleh 5 kategori lapangan usaha, sebagaimana tersaji dalam Tabel 1.

Tabel 1. Distribusi Persentase dari 5 Lapangan Usaha yang Mendominasi PDRB Kabupaten Ciamis Tahun 2014-2018

\begin{tabular}{|c|c|c|c|c|c|c|c|}
\hline & Lapangan Usaha & 2014 & 2015 & 2016 & 2017 & 2018 & Rata-rata \\
\hline A & Pertanian, Kehutanan dan Perikanan & 25,42 & 24,42 & 24,34 & 23,64 & 23,74 & 24,31 \\
\hline B & $\begin{array}{l}\text { Pedagang besar dan Eceran; Reparasi Mobil } \\
\text { dan Sepeda Motor }\end{array}$ & 0,23 & 0,22 & 0,20 & 0,18 & 0,17 & 0,20 \\
\hline $\mathrm{C}$ & Transportasi dan Pergudangan & 7,50 & 7,60 & 7,71 & 7,64 & 7,62 & 7,61 \\
\hline $\mathrm{D}$ & Konstruksi & 9,09 & 8,97 & 8,75 & 8,88 & 9,10 & 8,96 \\
\hline $\mathrm{E}$ & Industri Pengolahan & 7,50 & 7,60 & 7,71 & 7,64 & 7,62 & 7,61 \\
\hline
\end{tabular}

Tabel 1 menunjukan bahwa sektor pertanian, kehutanan dan perikanan memiliki kontribusi yang cukup besar dalam perekonomian Kabupaten Ciamis dengan rata-rata distribusi persentase sebesar 24,31 persen artinya kegiatan perekonomian Kabupaten Ciamis masih didominasi oleh sektor pertanian. Hal tersebut tidak lepas dari peran sub sektor pertanian lainnya, yaitu sub sektor tanaman bahan makanan, tanaman perkebunan, peternakan, perikanan dan kehutanan. Hasil produksi sub sektor peternakan menurut Dinas Peternakan 
dan Perikanan Kabupaten Ciamis selama periode 2014-2018 mengalami pertumbuhan yang baik yaitu sebesar $82,62 \%$. Kontribusi yang besar mesti diikuti dengan peningkatan kesejahteraan masyarakat. Peningkatan kesejahteraan masyarakat melalui penyerapan tenaga kerja dapat dilakukan dengan mengetahui sub sektor pertanian mana yang menjadi sektor unggulan (sektor basis dan non basis), sehingga dapat diketahui komoditas unggulan, yang mana sektor basis tersebut diharapkan dapat menyerap tenaga kerja.

Strategi pembangunan di Kabupaten Ciamis pada sub sektor peternakan dapat diarahkan pada prioritas pengembangan komoditas basis atau unggulan. Berdasarkan pandangan teori basis ekonomi, bahwa kegiatan basis dapat mendorong pertumbuhan ekonomi suatu wilayah (Tarigan, 2005). Oleh sebab itu, penentuan prioritas pengembangan komoditas unggulan perlu dilakukan oleh pemerintah daerah Kabupaten Ciamis untuk meningkatkan pertumbuhan dan keseimbangan antar wilayah kecamatan. Adanya penentuan komoditas unggulan juga dapat memudahkan pemerintah daerah dalam membuat perencanaan dan pengambilan kebijakan pembangunan wilayah kecamatan di Kabupaten Ciamis sehingga mampu mempertahankan dan meningkatkan peranan subsektor peternakan dalam perekonomian daerah.

Potensi peternakan yang ada di Kabupaten Ciamis tidak terlepas dari potensi yang ada di tingkat kecamatan sehingga perlu adanya upaya untuk mengoptimalkan sumber daya yang ada di kecamatan, dalam hal ini adalah komoditas-komoditas peternakan, sehingga untuk mengetahui potensi ekonomi dari sub sektor peternakan dapat dilakukan dengan mengetahui komoditas peternakan yang menjadi komoditas basis. Selain itu juga perlu diketahui pertumbuhan dari komoditas-komoditas peternakan tersebut, sehingga dapat diketahui komoditas peternakan yang menjadi unggulan. Berdasarkan hal tersebut maka penulis tertarik untuk melakukan analisis komoditas peternakan unggulan di Kabupaten Ciamis yang berpotensi untuk dikembangkan, sehingga pembangunan wilayah kecamatan di Kabupaten Ciamis dapat lebih terarah dan efisien.

\section{METODE PENELITIAN}

Metode penelitian yang digunakan adalah studi kasus terhadap komoditas peternakan di Kabupaten Ciamis. Jenis 
data yang digunakan dalam penelitian ini adalah data sekunder berupa data time series selama 6 tahun (2013 sampai dengan 2018). Data yang digunakan adalah data produksi komoditas peternakan (daging dan telur) tiap-tiap kecamatan di Kabupaten Ciamis Tahun 2013-2018. Kemudian metode pengumpulan data yang digunakan dalam penelitian ini yaitu melalui observasi non partisipan, karena data yang digunakan merupakan data sekunder yang diperoleh dari instansi pemerintah atau lembaga terkait diantaranya Dinas Peternakan dan Perikanan Kabupaten Ciamis, Dinas Pertanian Kabupaten Ciamis, Badan Perencana Pembangunan Daerah (BAPPEDA) Kabupaten Ciamis dan Badan Pusat Statistik (BPS) Kabupaten Ciamis, jurnal-jurnal penelitian, serta literatur-literatur lain dan hasil penelitian yang relevan dengan penelitian ini.

\section{A. Analisis Penentuan Komoditas} Peternakan Basis

Penentuan komoditas peternakan basis dari tiap-tiap kecamatan di Kabupaten Ciamis menggunakan metode analisis Location Quotient (LQ). Menurut Kuncoro (2018), analisis LQ terbagi atas Static Location Quotient (SLQ) dan Dynamic Location Quotient (DLQ).

Pengaplikasian rumus dalam
menganalisis data dibantu dengan
Microsoft Excel 2016.

Analisis SLQ digunakan untuk melihat kemampuan suatu daerah dalam menghasilkan suatu komoditas yang mana komoditas tersebut dapat diekspor ke luar daerahnya atau sebaliknya malah impor dari daerah luar daerah. Secara matematis SLQ dapat dirumuskan sebagai berikut:

$$
\frac{\mathrm{Xij} / \sum \mathrm{Xij}}{\mathrm{Xik} / \sum \mathrm{Xik}}
$$

Keterangan:

Xij : produksi komoditas ternak jenis $i$ di kecamatan.

$\sum X i j \quad$ : produksi komoditas ternak yang ada di kecamatan.

Xik : produksi komoditas ternak jenis $i$ di Kabupaten Ciamis

$\sum X i k$ : produksi komoditas ternak yang ada di Kabupaten Ciamis

Kriteria keputusan:

1) Nilai SLQ $>1$, artinya komoditas peternakan tersebut merupakan basis.

2) Nilai $\operatorname{SLQ}=1$, artinya komoditas peternakan tersebut merupakan non basis.

3) Nilai SLQ $<1$, artinya komoditas peternakan tersebut merupakan non basis. 
Sedangkan untuk analisis pergeseran peran komoditas peternakan menggunakan metode analisis Dynamic Location Quotient (DLQ). Analisis DLQ digunakan untuk menentukan reposisi komoditas peternakan basis apakah komoditas peternakan tersebut dapat tetap bertahan sebagai komoditas peternakan basis atau mengalami pergeseran. Secara matematis dapat dirumuskan sebagai berikut:

$$
\operatorname{DLQ}_{\mathrm{ij}}=\int^{\left(1+\mathrm{g}_{\mathrm{ij}}\right) /(1+\mathrm{g}}
$$

Keterangan:

gij : laju pertumbuhan produksi ternak i di kecamatan.

gj : rata-rata laju pertumbuhan produksi ternak di kecamatan.

Gik : laju pertumbuhan produksi ternak i di Kabupaten Ciamis.

Gk : rata-rata laju pertumbuhan produksi ternak di Kabupaten Ciamis.

t : selisih tahun awal dan tahun akhir.

Kriteria keputusan:

1) Nilai DLQ $>1$ menunjukan potensi pengembangan komoditas peternakan tersebut lebih cepat dibandingkan komoditas yang sama di Kabupaten.

2) Nilai $D L Q<1$ menunjukan potensi pengembangan komoditas peternakan tersebut lebih rendah dibandingkan komoditas yang sama di Kabupaten.

Klasifikasi komoditas peternakan berdasarkan gabungan Nilai SLQ dan DLQ tersaji dalam Tabel 2.

Tabel 2. Gabungan Nilai Hasil Analisis SLQ dan DLQ

\begin{tabular}{l|ll}
\hline Kriteria & SLQ $>1$ & SLQ $<1$ \\
\hline DLQ $>1$ & Unggulan & Andalan \\
DLQ $<1$ & Prospektif & Tertinggal
\end{tabular}

Sumber: Mudrajad Kuncoro (2018)

Keterangan:

a. DLQ $>1$ dan SLQ>1 artinya tidak terjadi pergeseran, komoditas basis dan ke depannya masih tetap menjadi komoditas basis. Komoditas tersebut menjadi komoditas unggulan.

b. DLQ $>1$ dan SLQ $<1$ artinya terjadi pergeseran dari komoditas non basis dan menjadi komoditas basis. Komoditas tersebut menjadi komoditas andalan.

c. $\mathrm{DLQ}<1$ dan SLQ $>1$ artinya terjadi pergeseran dari komoditas basis dan ke depannya komoditas tersebut menjadi komoditas non basis. Komoditas tersebut menjadi komoditas prospektif.

d. $\mathrm{DLQ}<1$ dan $\mathrm{SLQ}<1$ artinya tidak terjadi pergeseran dari komoditas non basis dan kedepannya masih tetap menjadi komoditas basis. Komoditas tersebut tertinggal. 
B. Analisis Pertumbuhan Komoditas Peternakan

Analisis pertumbuhan dari komoditas peternakan di wilatah kecamatan di Kabupaten Ciamis dilakukan dengan analisis Shift Share. Analisi Shift Share juga dapat digunakan untuk menutupi kelemahan dari analisis LQ dalam penentuan komoditas unggulan. Analisis Shift Share terdiri atas tiga komponen yaitu Pertumbuhan Regional, Pertumbuhan Proporsional, dan Pertumbuhan Pangsa Wilayah. Komponen pertumbuhan yang menjadi fokus dalam penelitian ini adalah Pertumbuhan Proporsional dan Pertumbuhan Pangsa Wilayah, sebagaimana dikatakan oleh Firdaus (2007) dalam Wulandari (2011) bahwa komponen PP dan PPW dapat digunakan untuk menunjukan komoditas unggulan. Selain itu juga menurut Arief Daryanto dan Yundy Hafizrianda (2010) bahwa kriteria-kriteria komoditas unggulan salah satunya adalah progresif artinya komoditas tersebut harus dapat tumbuh secara berkelanjutan dengan laju yang cukup pesat, kemudian tangguh artinya komoditas tersebut harus meiliki daya saing dan ketahanan menghadapi gejolak ekonomi politik, globalisasi maupun alam.
Analisis Shift Share dalam penelitian ini secara matematis dapat dirumuskan sebagai berikut:

$$
\begin{aligned}
& P_{i j}=Y_{i j}(R i-R a) \\
& P P W_{i j}=Y_{i j}(r i-R i)
\end{aligned}
$$

Keterangan:

$\mathrm{Y}_{\mathrm{ij}} \quad=$ produksi komoditas peternakan i di kecamatan $\mathrm{j}$ pada tahun dasar analisis.

$\mathrm{Y}^{\prime}{ }_{\mathrm{ij}} \quad=$ produksi komoditas peternakan i di kecamatan $\mathrm{j}$ pada tahun akhir analisis. $\mathrm{Y}_{\mathrm{ik}} \quad=$ produksi komoditas peternakan i di Kabupaten Ciamis pada tahun dasar analisis.

$\mathrm{Y}^{\prime}{ }_{\mathrm{ik}}=$ produksi komoditas peternakan i di Kabupaten Ciamis pada tahun akhir analisis.

Y.. $=$ produksi seluruh sub-sektor peternakan Kabupaten Ciamis pada tahun dasar analisis.

$\mathrm{Y}^{\prime} . . \quad=$ produksi seluruh sub sektor peternakan Kabupaten Ciamis pada tahun akhir analisis.

$$
\begin{array}{ll}
\text { Ra } & =Y^{\prime} . . / Y . . \\
\text { Ri } & =Y^{\prime} i k / Y i k \\
\text { ri } & =Y^{\prime} \text { ij/Yij }
\end{array}
$$

Kriteria keputusan:

1) Apabila nilai PP positif berarti bahwa komoditas peternakan (i) kecamatan yang dianalisis (j) tumbuh dengan cepat. Apabila nilai PP negatif berarti bahwa komoditas peternakan 
kecamatan yang dianalisis $(\mathrm{j})$ tumbuh dengan lambat.

2) Apabila nilai PPW positif berarti bahwa komoditas peternakan (i) kecamatan yang dianalisis (j) memiliki keuntungan kompetitif atau berdaya saing dibandingkan dengan komoditas peternakan yang sama di Kabupaten Ciamis. Apabila nilai PPW negatif berarti bahwa komoditas peternakan (i) kecamatan yang dianalisis (j) tidak memiliki keuntungan kompetitif atau tidak memiliki daya saing dibandingkan dengan komoditas peternakan yang sama di Kabupaten Ciamis.

\section{Penentuan Komoditas Unggulan}

\section{Peternakan di Kabupaten Ciamis}

Penentuan komoditas unggulan peternakan wilayah di Kabupaten Ciamis dilakukan dengan menggabungkan hasil analisis Location Quotient (LQ) dengan analisis komponen pertumbuhan. Kriteria dalam penentuan komoditas peternakan unggulan di Kabupaten Ciamis adalah apabila nilai $\mathrm{SLQ}>1$ dan $\mathrm{DLQ}>1$, PP positif dan PPW positif, komoditas peternakan tersebut merupakan komoditas unggulan. Sedangkan untuk komoditas peternakan yang memiliki nilai SLQ $>1$ dan DLQ $>1$, PP positif dan PPW negatif atau SLQ $>1$ dan DLQ $>1$, PP negatif dan PPW positif, bukan merupakan komoditas unggulan tetapi dapat dikategorikan sebagai komoditas andalan $(\mathrm{SLQ}<1$ dan DLQ $>1$, PP negatif dan PPW negatif atau PP negatif PPW positif), komoditas prospektif (SLQ $>1$ dan DLQ $<1$, PP negatif dan PPW negatif atau PP negatif dan PPW positif) dan komoditas tertinggal $(\mathrm{SLQ}<1$ dan DLQ $<1$, PP negatif dan PPW negatif atau PP negatif dan PPW positif).

\section{HASIL DAN PEMBAHASAN}

\section{A. Komoditas Peternakan Basis dan Non Basis di Wilayah Kecamatan di Kabupaten Ciamis}

Komoditas peternakan basis dan non basis di wilayah kecamatan di Kabupaten Ciamis ditentukan melalui gabungan analisis SLQ dan DLQ. Menurut Mudrajat Kuncoro (2018) hasil gabungan analisis SLQ dan DLQ dapat dikategorikan menjadi 4 kategori yaitu: a) Komoditas unggulan, b) Komoditas andalan, c) Komoditas prospektif, dan d) Komoditas tertinggal. Gambaran jelas mengenai hasil gabungan analisi SLQ dan DLQ dapat dilihat dalam Tabel 3. 
komoditas prospektif tersebar di 10 kecamatan, komoditas kambing tersebar di 9 kecamatan dan ayam buras tersebar di 13 kecamatan. Hal tersebut terjadi karena peranan komoditas-komoditas tersebut lebih besar dibanding dengan komoditas yang sama di Kabupaten Ciamis namun kedepannya tidak dapat diharapkan karena peranannya dapat berubah menjadi lebh kecil dibanding dengan komoditas yang sama di Kabupaten Ciamis.

Komoditas ayam ras pedaging dan ayam ras petelur di wilayah kecamatan di Kabupaten Ciamis sebagian besar berada pada posisi atau kategori komoditas tertinggal. Komoditas ayam ras pedaging berkategori komoditas tertinggal tersebar di 13 kecamatan dan komoditas ayam ras petelur tersebar di 15 kecamatan. Hal tersebut terjadi karena peranan komoditas ayam ras pedaging di 13 kecamatan tersebut lebih kecil dibanding dengan komoditas yang sama di Kabupaten Ciamis dan kedepannya juga tidak dapat diharapkan karena masih memiliki peran yang lebih kecil dibanding dengan di Kabupaten Ciamis (SLQ $<1$ dan DLQ $<1)$.
Komoditas itik di wilayah kecamatan di Kabupaten Ciamis sebagian besar menduduki posisi atau kategori komoditas prospektif yaitu tersebar di 9 kecamatan, karena peranan komoditas itik lebih besar dibanding dengan komoditas yang sama di Kabupaten Ciamis namun kedepannya tidak dapat diharapkan karena peranannya dapat berubah menjadi lebih kecil dibanding dengan komoditas yang sama di Kabupaten Ciamis.

Berdasarkan uraian di atas kriteria komoditass peternakan yang dijadikan basis dalam penelitian ini adalah komoditas yang ada pada posisi atau dikategorikan unggulan yaitu memiliki nilai SLQ $>1$ dan DLQ $>1$. Komoditas peternakan yang menjadi basis (SLQ $>1$ dan DLQ $>1$ ) di wilayah kecamatan Kabupaten Ciamis adalah komoditas sapi potong, domba, kambing, ayam buras, ayam ras pedaging, ayam ras petelur dan itik. Gambaran jelas mengenai persebaran komoditas peternakan basis di wilayah kecamatan di Kabupaten Ciamis dapat diliha dalam Tabel 4. 
Tabel 4. Matriks Komoditas Peternakan Basis dan Non Basis di Wilayah Kecamatan di Kabupaten Ciamis

\begin{tabular}{|c|c|c|c|c|c|c|c|c|}
\hline \multirow[b]{2}{*}{ No } & \multirow[b]{2}{*}{ Kecamatan } & \multicolumn{7}{|c|}{ Komoditas peternakan } \\
\hline & & Sapi potong & Domba & Kambing & Ayam buras & $\begin{array}{l}\text { Ayam ras } \\
\text { pedaging }\end{array}$ & $\begin{array}{l}\text { Ayam ras } \\
\text { petelur }\end{array}$ & Itik \\
\hline 1 & Banjarsari & $\checkmark$ & $\checkmark$ & $\checkmark$ & $\checkmark$ & - & - & - \\
\hline 2 & Lakbok & - & $\checkmark$ & $\checkmark$ & - & - & - & - \\
\hline 3 & Pamarican & - & - & - & $\checkmark$ & - & - & $\checkmark$ \\
\hline 4 & Cidolog & - & - & - & $\checkmark$ & - & - & - \\
\hline 5 & Cimaragas & - & $\checkmark$ & $\checkmark$ & - & - & - & - \\
\hline 6 & Cijeungjing & - & - & $\checkmark$ & - & - & $\checkmark$ & - \\
\hline 7 & Cisaga & - & - & - & - & - & - & - \\
\hline 8 & Tambaksari & - & - & - & $\checkmark$ & $\checkmark$ & - & - \\
\hline 9 & Rancah & - & - & - & $\checkmark$ & $\checkmark$ & - & - \\
\hline 10 & Rajadesa & - & - & - & - & - & - & - \\
\hline 11 & Sukadana & - & - & - & - & - & - & $\checkmark$ \\
\hline 12 & Ciamis & $\checkmark$ & - & - & - & - & $\checkmark$ & - \\
\hline 13 & Cikoneng & - & - & - & - & - & - & - \\
\hline 14 & Cihaurbeuti & - & - & - & - & $\checkmark$ & - & - \\
\hline 15 & Sadananya & - & $\checkmark$ & $\checkmark$ & $\checkmark$ & - & - & - \\
\hline 16 & Cipaku & - & - & - & - & - & $\checkmark$ & - \\
\hline 17 & Jatinagara & - & - & - & - & $\checkmark$ & - & - \\
\hline 18 & Panawangan & - & - & - & - & $\checkmark$ & - & - \\
\hline 19 & Kawali & - & - & - & - & - & - & - \\
\hline 20 & Panjalu & - & - & - & - & - & $\checkmark$ & - \\
\hline 21 & Panumbangan & - & - & - & - & - & $\checkmark$ & - \\
\hline 22 & Sindangkasih & - & - & - & - & - & - & $\checkmark$ \\
\hline 23 & Baregbeg & - & - & - & - & - & - & - \\
\hline 24 & Lumbung & - & - & - & - & - & - & $\checkmark$ \\
\hline 25 & Purwadadi & $\checkmark$ & - & - & - & - & - & - \\
\hline 26 & Sukamantri & - & - & - & - & $\checkmark$ & - & - \\
\hline
\end{tabular}

(Sumber: Diolah dan Diadopsi dari Lampiran 8)

Ket: $(\checkmark)=$ komoditas peternakan basis; $(-)=$ komoditas peternakan non basis

Domba menjadi basis di Kecamatan Banjarsari, Lakbok, Cimaragas dan Sadananya. Oleh sebab itu kecamatankecamatan tersebut dapat mengekspor hasil produksi domba ke luar wilayahnya. Hal tersebut didukung oleh kondisi lingkungan Kabupaten Cimais yang cocok untuk pengembangan ternak domba yaitu curah hujan berkisar antara 1.500-3.000 mm/tahun, hal ini sesuai dengan pendapat Chris Dian F (2013) bahwa lokasi ternak domba yang ideal dilakukan di daerah dengan curah hujan 1.500-3.000 $\mathrm{mm} /$ tahun dengan kelembaban 60-80\%. Kemudian faktor pendukung lainnya adalah ketersediaan sumber pakan di kecamatan-kecamatan yang menjadi basis domba cukup luas yang diperoleh dari tegalan/kebun. 
Kambing menjadi basis di Kecamatan Banjarsari, Lakbok, Cimaragas, Cijeungjing dan Sadananya. Oleh sebab itu, kecamatan-kecamatan tersebut dapat mengekspor hasil produksi kambing ke luar wilayahnya. Hal tersebut didukung oleh ketersediaan sumber pakan hijauan di kecamatankecamatan tersebut yang melimpah yang dapat diperoleh dari lahan tegalan/kebun dan ladang/hutan.

Ayam buras menjadi basis di Kecamatan Banjarsari, Pamarican, Cidolog, Tambaksari, Rancah dan Sadananya. Oleh sebab itu kecamatankecamatan tersebut dapat mengekspor hasil produksi ayam buras ke luar wilayahnya. Hal tersebut didukung oleh upaya pemerintah dalam peningkatan hasil produksi ayam buras salah satunya dengan didirikannya balai pembibitan ayam sentul. Selain itu juga didukung oleh kondisi lingkungan yang cocok. Kecamatan-kecamatan tersebut cocok untuk pengembangan ternak ayam buras karena memiliki ketinggian wilayah 01.775 mdpl dan suhu antara $20-30^{\circ} \mathrm{C}$, hal ini sesuai dengan pendapat Muhammad Rasyaf (2011) bahwa tempat yang cocok untuk budidaya ayam buras yaitu tempat dengan ketinggian 0-1.500 mdpl dengan suhu ideal antara $18-25^{\circ} \mathrm{C}$. Kemudian faktor pendukung lainnya adalah ketersediaan sumber pakan yang masih melimpah berupa jagung dan kedelai yang diolah terlebih dahulu.

Ayam ras pedaging menjadi basis di Kecamatan Tambaksari, Rancah, Cihaurbeuti, Jatinagara, Panawangan dan Sukamantri. Oleh sebab itu, kecamatankecamatan tersebut dapat mengekspor hasil produksi ayam ras pedaging ke luar wilayahnya. Ayam ras pedaging sudah lama dikembangkan dan merupakan ternak dengan tingkat produksi terbesar di Kabupaten Ciamis bahkan Kabupaten Ciamis menjadi salah satu sentra dari ayam ras pedaging di Jawa Barat. Sehingga ayam ras pedaging menjadi komoditas peternakan yang paling banyak menjadi basis di wilayah kecamtan di Kabupaten Ciamis. Kecamatan-kecamatan tersebut cocok sebagai tempat pengembangan ayam ras pedaging didukung oleh lingkungan yang cocok untuk pengembangan ayam ras pedaging yaitu rata-rata suhu di kecamtan-kecamatan tersebut antara 20$30^{\circ} \mathrm{C}$, hal ini sebagaimana dijelaskan oleh Mitra Agro Sejati (2017) bahwa lokasi kandang yang nyaman dan berkonstruksi baik untuk ayam ras pedaging atau broiler, apabila memiliki ventilasi kandang yang baik dengan suhu $21-27^{\circ} \mathrm{C}$ 
dengan kelembaban $60 \%$ di dalam kandang. Selain faktor lingkungan, kecamatan-kecamatan tersebut memiliki sumber pakan yang melimpah seperti jagung dan kedelai.

Ayam ras petelur menjadi basis di Kecamatan Cijeungjing, Ciamis, Cipaku, Panjalu dan Panumbangan. Oleh sebab itu, kecamatan-kecamatan tersebut dapat mengekspor hasil produksi ayam ras petelur ke luar wilayahnya. Produksi ayam ras petelur di Kabupaten Ciamis merupakan kedua terbanyak setelah ayam ras pedaging, hal tersebut terjadi karena sudah banyak investor atau pengusaha besar yang tertarik untuk mengusahakannya sehingga skala usaha ternak ayam ras petelur relatif besar. Selain itu, juga didukung oleh kondisi lingkungan yang cocok untuk pengembangan ayam ras petelur yaitu ketinggian wilayah antara 300-700 mdpl dengan suhu berkisar antara $20-30^{\circ} \mathrm{C}$, hal ini sesuai dengan yang dijelaskan oleh Mitra Agro Sejati (2017) bahwa lokasi yang ideal untuk peternakan ayam ras petelur yaitu lokasi berada di dataran medium yang tingginya antara 300-700 mdpl, suhu antara $20-26^{\circ} \mathrm{C}$ dan kelembaban relatif antara 50-70\%. Selain faktor lingkungan, sumber pakan di kecamatan-kecamatan tersebut cukup melimpah berupa jagung dan kedelai.

Itik menjadi basis di Kecamatan Pamarican, Sukadana, Sindangkasih, dan Lumbung. Oleh sebab itu kecamatankecamatan tersebut dapat mengekspor hasil produksi sapi potong ke luar wilayahnya. Hal tersebut didukung oleh ketersediaan sumber pakan di kecamatankecamatan tersebut yang masih melimpah berupa jagung dan kedelai. Peran pemerintah untuk menjaga keberlangsungan usaha ternak itik sangat diperlukan mengingat belum adanya investor atau pengusaha besar yang tertarik dalam usaha ternak itik.

\section{B. Pertumbuhan}

Komoditas

Peternakan di Wilayah Kecamatan di Kabupaten Ciamis

Pertumbuhan komoditas peternakan di wilayah kecamatan di Kabupaten Ciamis dilihat dari nilai Pertumbuhan Proporsional (PP) dan Pertumbuhan Pangsa Wilayah (PPW) dari hasil analisis Shift Share untuk memperoleh gambaran yang spesifik mengenai pertumbuhan komoditas peternakan dapat dilihat pada Tabel 5.

Sapi potong memiliki pertumbuhan yang cepat di semua kecamatan sehingga semua kecamatan dapat dikatakan sebagai daerah yang terspesialisasi untuk 
mengembangkan sapi potong. Hal tersebut dapat dilihat dari tingkat produksi daging sapi dari tahun ke tahun menurut Dinas Peternakan dan Perikanan Kabupaten Ciamis (2013-2018) mengalami peningkatan. Tahun 2013 sebanyak $624.425 \mathrm{~kg}$ dan pada tahun 2018 menjadi $1.167 .964 \mathrm{~kg}$. Hal tersebut didukung dengan adanya Upaya khusus dari pemerintah yaitu UPSUS SIWAB (Upaya Khusus Sapi Induk Wajib Bunting) sehingga melalui upaya-upaya tersebut populasi sapi bertambah dan hasil produksi meningkat. Kemudian sapi potong memiliki nilai Pertumbuhan Pangsa Wilayah (PPW) positif artinya sapi potong mampu berdaya saing di 6 kecamatan. Sapi potong di kecamatankecamatan tersebut memiliki prospek pengembangan yang besar dengan kondisi alam yang mendukung seperti banyak terdapat rerumputan atau tanaman hijauan sebagai sumber pakan. Oleh sebab itu, ke depannya hal tersebut harus dipertahankan dengan melaksanakan pengolahan alam/lingkungan yang berkelanjutan sehingga alam tetap lestari.

Domba memiliki nilai Pertumbuhan Proporsional (PP) negatif artinya domba mengalami pertumbuhan yang lambat di semua kecamatan. Oleh sebab itu, semua kecamatan tidak menjadi daerah yang terspesialisasi untuk mengembangkan domba. Hal tersebut dapat dilihat dari produksi daging ternak domba dari tahun ke tahun menurut Dinas Peternakan dan Perikanan Kabupaten Ciamis (20132018) mengalami kenaikan namun tidak sebesar komoditas lainnya. Tahun 2013 produksi daging domba sebanyak $398.312 \mathrm{~kg}$ dan pada tahun 2018 sebanyak $456.146 \mathrm{~kg}$. Kenaikan tingkat produksi tidak begitu besar karena permintaan terhadap daging domba tidak sebesar daging ternak lainnya seperti daging sapi atau unggas. Meski memiliki pertumbuhan yang lambat akan tetapi domba masih memiliki daya saing yang baik dilihat dari nilai Pertumbuhan Pangsa Wilayah (PPW) positif di 14 kecamatan. Ternak domba di kecamatankecamatan tersebut memiliki prospek pengembangan yang besar dengan harga yang stabil dan didukung oleh sumber pakan di kecamatan-kecamatan tersebut yang masih melimpah.

Kambing memiliki nilai Pertumbuhan Proporsional (PP) negatif artinya kambing mengalami pertumbuhan yang lambat di setiap kecamatan. Oleh sebab itu, kecamatan-kecamatan tersebut tidak menjadi daerah yang terspesialisasi untuk mengembangkan kambing dilihat 
dari tingkat produksi daging kambing dari tahun ke tahun menurut Dinas Peternakan dan Perikanan Kabupaten Ciamis (2013-2018) mengalami kenaikan namun tidak sebesar komoditas lainnya. Tahun 2013 produksi daging kambing sebanyak $307.627 \mathrm{~kg}$, dan pada tahun 2018 sebanyak 340.670 kg. Kambing memiliki kenaikan hasil produksi yang tidak terlalu besar bahkan lebih kecil dari domba, karena kambing juga memiliki tingkat permintaan yang kecil dan terbatas tidak seperti daging sapi dan unggas. Kemudian kambing berdasarkan nilai Pertumbuhan Pangsa Wilayah (PPW) menunjukan bahwa kambing memiliki daya saing yang baik (lampiran 12) di 12 kecamatan. Kambing di kecamatan-kecamatan tersebut memiliki prospek pengembangan yang besar didukung dengan sumber pakan hijauan yang melimpah.

Tabel 5. Matriks Pertumbuhan Komoditas Peternakan di Wilayah Kecamatan Di Kabupaten Ciamis

\begin{tabular}{|c|c|c|c|c|c|c|c|c|c|c|c|c|c|c|c|}
\hline \multirow{3}{*}{ No } & \multirow{3}{*}{ Kecamatan } & \multicolumn{14}{|c|}{ Komoditas peternakan } \\
\hline & & \multicolumn{2}{|c|}{ Sapi potong } & \multicolumn{2}{|c|}{ Domba } & \multicolumn{2}{|c|}{ Kambing } & \multicolumn{2}{|c|}{ Ayam buras } & \multicolumn{2}{|c|}{$\begin{array}{l}\text { Ayam ras } \\
\text { pedaging }\end{array}$} & \multicolumn{2}{|c|}{$\begin{array}{c}\text { Ayam ras } \\
\text { petelur }\end{array}$} & \multicolumn{2}{|c|}{ Itik } \\
\hline & & PP & PPW & PP & PPW & PP & PPW & PP & PPW & PP & PPW & PP & PPW & PP & PPW \\
\hline 1 & Banjarsari & $\checkmark$ & $\checkmark$ & $\mathrm{O}$ & $\checkmark$ & $\mathrm{O}$ & $\checkmark$ & $\mathrm{O}$ & $\checkmark$ & $\mathrm{O}$ & - & $\checkmark$ & $\checkmark$ & $\mathrm{O}$ & $\checkmark$ \\
\hline 2 & Lakbok & $\checkmark$ & $\checkmark$ & $\mathrm{O}$ & $\checkmark$ & $\mathrm{O}$ & $\checkmark$ & $\mathrm{O}$ & - & $\mathrm{O}$ & - & $\checkmark$ & - & $\mathrm{O}$ & $\checkmark$ \\
\hline 3 & Pamarican & $\checkmark$ & - & $\mathrm{O}$ & - & $\mathrm{O}$ & - & $\mathrm{O}$ & $\checkmark$ & $\mathrm{O}$ & - & $\checkmark$ & - & $\mathrm{O}$ & $\checkmark$ \\
\hline 4 & Cidolog & $\checkmark$ & - & $\mathrm{O}$ & - & $\mathrm{O}$ & - & $\mathrm{O}$ & $\checkmark$ & $\mathrm{O}$ & - & $\checkmark$ & - & $\mathrm{O}$ & - \\
\hline 5 & Cimaragas & $\checkmark$ & - & $\mathrm{O}$ & $\checkmark$ & $\mathrm{O}$ & $\checkmark$ & $\mathrm{O}$ & - & $\mathrm{O}$ & - & $\checkmark$ & - & $\mathrm{O}$ & - \\
\hline 6 & Cijeungjing & $\checkmark$ & - & $\mathrm{O}$ & $\checkmark$ & $\mathrm{O}$ & $\checkmark$ & $\mathrm{O}$ & - & $\mathrm{O}$ & - & $\checkmark$ & $\checkmark$ & $\mathrm{O}$ & - \\
\hline 7 & Cisaga & $\checkmark$ & - & $\mathrm{O}$ & $\checkmark$ & $\mathrm{O}$ & - & $\mathrm{O}$ & $\checkmark$ & $\mathrm{O}$ & $\checkmark$ & $\checkmark$ & $\checkmark$ & $\mathrm{O}$ & - \\
\hline 8 & Tambaksari & $\checkmark$ & - & $\mathrm{O}$ & - & $\mathrm{O}$ & - & $\mathrm{O}$ & $\checkmark$ & $\mathrm{O}$ & $\checkmark$ & $\checkmark$ & - & $\mathrm{O}$ & - \\
\hline 9 & Rancah & $\checkmark$ & - & $\mathrm{O}$ & - & $\mathrm{O}$ & - & $\mathrm{O}$ & $\checkmark$ & $\mathrm{O}$ & $\checkmark$ & $\checkmark$ & - & $\mathrm{O}$ & - \\
\hline 10 & Rajadesa & $\checkmark$ & - & $\mathrm{O}$ & - & $\mathrm{O}$ & $\checkmark$ & $\mathrm{O}$ & - & $\mathrm{O}$ & - & $\checkmark$ & - & $\mathrm{O}$ & - \\
\hline 11 & Sukadana & $\checkmark$ & $\checkmark$ & $\mathrm{O}$ & $\checkmark$ & $\mathrm{O}$ & - & $\mathrm{O}$ & - & $\mathrm{O}$ & - & $\checkmark$ & - & $\mathrm{O}$ & $\checkmark$ \\
\hline 12 & Ciamis & $\checkmark$ & $\checkmark$ & $\mathrm{O}$ & $\checkmark$ & $\mathrm{O}$ & $\checkmark$ & $\mathrm{O}$ & $\checkmark$ & $\mathrm{O}$ & - & $\checkmark$ & $\checkmark$ & $\mathrm{O}$ & $\checkmark$ \\
\hline 13 & Cikoneng & $\checkmark$ & - & $\mathrm{O}$ & $\checkmark$ & $\mathrm{O}$ & $\checkmark$ & $\mathrm{O}$ & - & $\mathrm{O}$ & - & $\checkmark$ & - & $\mathrm{O}$ & - \\
\hline 14 & Cihaurbeuti & $\checkmark$ & - & $\mathrm{O}$ & - & $\mathrm{O}$ & - & $\mathrm{O}$ & $\checkmark$ & $\mathrm{O}$ & $\checkmark$ & $\checkmark$ & - & $\mathrm{O}$ & $\checkmark$ \\
\hline 15 & Sadananya & $\checkmark$ & - & $\mathrm{O}$ & $\checkmark$ & $\mathrm{O}$ & $\checkmark$ & $\mathrm{O}$ & $\checkmark$ & - & - & $\checkmark$ & - & $\mathrm{O}$ & $\checkmark$ \\
\hline 16 & Cipaku & $\checkmark$ & - & $\mathrm{O}$ & - & $\mathrm{O}$ & - & $\mathrm{O}$ & $\checkmark$ & $\mathrm{O}$ & - & $\checkmark$ & $\checkmark$ & $\mathrm{O}$ & - \\
\hline 17 & Jatinegara & $\checkmark$ & - & $\mathrm{O}$ & - & $\mathrm{O}$ & - & $\mathrm{O}$ & $\checkmark$ & $\mathrm{O}$ & $\checkmark$ & $\checkmark$ & - & $\mathrm{O}$ & - \\
\hline 18 & Panawangan & $\checkmark$ & - & $\mathrm{O}$ & - & $\mathrm{O}$ & - & $\mathrm{O}$ & $\checkmark$ & $\mathrm{O}$ & $\checkmark$ & $\checkmark$ & - & $\mathrm{O}$ & $\checkmark$ \\
\hline 19 & Kawali & $\checkmark$ & - & $\mathrm{O}$ & - & $\mathrm{O}$ & $\checkmark$ & $\mathrm{O}$ & $\checkmark$ & $\mathrm{O}$ & $\checkmark$ & $\checkmark$ & - & $\mathrm{O}$ & - \\
\hline 20 & Panjalu & $\checkmark$ & - & $\mathrm{O}$ & - & $\mathrm{O}$ & - & $\mathrm{O}$ & - & $\mathrm{O}$ & - & $\checkmark$ & $\checkmark$ & $\mathrm{O}$ & $\checkmark$ \\
\hline 21 & Panumbangan & $\checkmark$ & - & $\mathrm{O}$ & $\checkmark$ & $\mathrm{O}$ & - & $\mathrm{O}$ & - & $\mathrm{O}$ & - & $\checkmark$ & $\checkmark$ & $\mathrm{O}$ & $\checkmark$ \\
\hline 22 & Sindangkasih & $\checkmark$ & - & $\mathrm{O}$ & $\checkmark$ & $\mathrm{O}$ & - & $\mathrm{O}$ & - & $\mathrm{O}$ & - & $\checkmark$ & - & $\mathrm{O}$ & $\checkmark$ \\
\hline 23 & Baregbeg & $\checkmark$ & - & $\mathrm{O}$ & $\checkmark$ & $\mathrm{O}$ & $\checkmark$ & $\mathrm{O}$ & - & $\mathrm{O}$ & - & $\checkmark$ & - & $\mathrm{O}$ & - \\
\hline 24 & Lumbung & $\checkmark$ & $\checkmark$ & $\mathrm{O}$ & $\checkmark$ & $\mathrm{O}$ & $\checkmark$ & $\mathrm{O}$ & - & $\mathrm{O}$ & - & $\checkmark$ & - & $\mathrm{O}$ & $\checkmark$ \\
\hline 25 & Purwadadi & $\checkmark$ & $\checkmark$ & $\mathrm{O}$ & $\checkmark$ & $\mathrm{O}$ & $\checkmark$ & $\mathrm{O}$ & - & $\mathrm{O}$ & - & $\checkmark$ & - & $\mathrm{O}$ & $\checkmark$ \\
\hline 26 & Sukamantri & $\checkmark$ & - & $\mathrm{O}$ & - & $\mathrm{O}$ & - & $\mathrm{O}$ & - & $\mathrm{O}$ & $\mathrm{O}$ & $\checkmark$ & - & $\mathrm{O}$ & - \\
\hline
\end{tabular}

(Sumber: Diolah dan Diadopsi dari Lampiran 10 dan 12)

Ket: $(\checkmark)=$ PP positif dan PPW positif; $(\mathrm{O})=$ PP negatif dan PPW negatif 
Ayam buras memiliki nilai Pertumbuhan Proporsional (PP) negatif artinya ayam buras mengalami pertumbuhan yang lambat di semua kecamatan. Oleh sebab itu, kecamatankecamatan tersebut tidak menjadi daerah yang terspesialisasi untuk mengembangkan ayam buras dilihat dari produksi daging ayam buras dari tahun ke tahun menurut Dinas Peternakan dan Perikanan Kabupaten Ciamis (20132018) mengalami penurunan. Tahun 2013 produksi daging ayam buras sebanyak $1.431 .643 \mathrm{~kg}$ dan pada tahun 2018 menurun menjadi $912.826 \mathrm{~kg}$. Hal tersebut terjadi karena banyaknya peternak yang beralih untuk mengusahakan ayam ras karena usaha ayam ras dirasa lebih menguntungkan. Usaha ayam buras masih didominasi oleh peternakan rakyat dengan skala kepemilikan yang kecil dan minim teknologi. Pemerintah daerah dalam upaya pengembangan ayam buras telah mendirikan balai benih ayam buras (ayam sentul), akan tetapi belum bisa meningkatkan produksi ayam buras dan meningkatkan kesejahteraan peternak. Kemudian ayam buras berdasarkan nilai Pertumbuhan Pangsa Wilayah (PPW) (lampiran 12) menunjukan bahwa ayam buras memiliki daya saing yang baik di
14 kecamatan. Ayam buras di kecamatankecamatan tersebut memiliki prospek pengembang yang besar didukung oleh ketersediaan pakan berupa jagung dan kedelai yang cukup melimpah.

Ayam ras pedaging memiliki nilai Pertumbuhan Proporsional (PP) negatif artinya ayam ras pedaging mengalami pertumbuhan yang lambat di setiap kecamatan. Oleh sebab itu kecamatankecamatan tersebut tidak menjadi daerah yang terspesialisasi untuk mengembangkan ayam ras pedaging dilihat dari produksi daging ayam ras pedaging dari tahun ke tahun menurut Dinas Peternakan dan Perikanan Kabupaten Ciamis (2013-2018) mengalami peningkatan namun pertumbuhannya lambat. Tahun 2013 sebesar $96.014 .831 \mathrm{~kg}$ dan tahun 2018 menjadi $117.270 .628 \mathrm{~kg}$. Ayam ras pedaging sudah cukup lama dikembangkan di Kabupaten Ciamis dilihat dari banyaknya peternak yang mengusahakan ayam ras pedaging. Selain itu, juga sudah banyak investor atau pengusaha besar yang tertarik untuk mengusahakannya dan dibantu dengan adanya teknologi sehingga tingkat produksinya tinggi. Hal tersebut yang mengakibatkan pertumbuhan ayam ras pedaging menjadi lambat karena pada 
awal berkembang produksinya sudah tinggi sehingga pertumbuhannya kecil atau dengan kata lain kapasitas produksi di Kabupaten Ciamis sudah optimum dan jika terus ditingakatkan maka akan terjadi ketidakstabilan antara supply dan demand. Kemudian ayam ras pedaging memiliki nilai Pertumbuhan Pangsa Wilayah (PPW) positif artinya ayam ras pedaging mampu berdaya saing atau memiliki keunggulan kompetitif di 7 kecamatan. Ayam ras pedaging di kecamatan-kecamatan tersebut memiliki prospek pengembangan yang besar didukung oleh ketersediaan pakan berupa jagung dan kedelai yang masih melimpah.

Ayam ras petelur memiliki nilai Pertumbuhan Proporsional (PP) positif artinya ayam ras petelur mengalami pertumbuhan yang cepat di semua kecamatan. Oleh sebab itu, kecamatankecamatan tersebut menjadi daerah yang terspesialisasi untuk membudidayakan ayam ras petelur dilihat dari hasil produksi telur ayam ras petelur dari tahun ke tahun menurut Dinas Peternakan dan Perikanan Kabupaten Ciamis (20132018) mengalami peningkatan. Tahun 2013 produksi telur dari ayam ras petelur sebanyak $5.761 .593 \mathrm{~kg}$ dan pada tahun 2018 menjadi 11.439.926 kg.
Pertumbuhan dari produksi telur yang cepat karena permintaan terhadap telur khusunya telur ayam ras yang tinggi dibandingkan dengan telur yang berasal dari jenis unggas lainnya, hal tersebut menciptakan daya tarik bagi peternak dan investor atau pengusaha besar untuk mengusahakannya serta dibantu dengan pengembangan teknologi untuk mendukung meningkatkan produksi. Selain pertumbuhan yang cepat ayam ras petelur juga memiliki daya saing yang baik dilihat dari nilai Pertumbuhan Pangsa Wilayah (PPW) yang bernilai positif (lampiran 12) artinya ayam ras petelur mampu berdaya saing atau memiliki keungulan kompetitif di 6 kecamatan. Ayam ras petelur di kecamatan-kecamatan tersebut memiliki prospek pengembangan yang besar didukung oleh ketersediaan pakan berupa jagung dan kedelai yang masih melimpah.

Kemudian ternak itik berdasarkan hasil analisis mengalami pertumbuhan yang lambat di setiap kecamatan. Oleh sebab itu, kecamatan-kecamatan tersebut tidak menjadi daerah yang terspesialisasi untuk mengembangkan itik dilihat dari hasil produksi telur itik dari tahun ke tahun menurut Dinas Peternakan dan Perikanan Kabupaten Ciamis (2013- 
2018) cenderung menurun. Tahun 2013 produksi telur itik sebanyak $2.347 .032 \mathrm{~kg}$ dan pada tahun 2018 menjadi 1.128.536 $\mathrm{kg}$ penurunan tersebut dapat disebabkan karena penurunan permintaan telur itik. Selain itu juga pemanfaatan telur itik saat ini sebatas untuk telur asin dan jamu. Selain itu, kebanyakan peternak memelihara itik secara tradisional dan minim teknologi, sehingga hasil produksi belum optimum.

Meski demikian itik memiliki daya saing yang baik dilihat dari nilai Pertumbuhan Pangsa Wilayah (PPW) yang bernilai positif artinya itik mampu berdaya saing atau memiliki keunggulan kompetitif di 15 kecamatan. Itik di kecamatan-kecamatan tersebut memiliki prospek pengembangan yang besar didukung oleh ketersediaan pakan berupa jagung dan kedelai yang masih melimpah.

\section{Komoditas Peternakan Unggulan di} Wilayah Kecamatan di Kabupaten

\section{Ciamis}

Komoditas unggulan tentu harus berdaya saing. Sebagaimana dikatakan oleh Moch. Sulistyo Kurniawan, Sudarti, dan Zainal Arifin (2017) bahwa daya saing di era otonomi dan globalisasi menjadi kunci utama untuk mencapai kinerja pembangunan daerah yang bagus dan berkelanjutan karena tingkat daya saing (competitiveness) merupakan salah satu parameter dalam pembangunan daerah kabupaten/kota berkelanjutan. Sehingga dalam rangka pembangunan daerah maka komoditas peternakan yang menjadi komoditas peternakan unggulan dapat dijadikan sebagai prioritas utama untuk dikembangkan guna pembangunan daerah.

Berdasarkan hasil penggabungan analisis LQ dan komponen Pertumbuhan Proporsional (PP) dan Pertumbuhan Pangsa Wilayah (PPW) sapi potong menjadi komoditas unggulan di Kabupaten Ciamis. Komoditas sapi potong dikatakan unggulan karena merupakan komoditas basis dengan pertumbuhan yang cepat dan berdaya saing baik. Sedangkan menurut Dinas Peternakan dan Perikanan Kabupaten Ciamis (2020) ternak sapi juga menjadi komoditas unggulan di Kabupaten Ciamis. Jenis sapi yang dikembangkan adalah jenis sapi Pasundan/Rancah.

Saat ini Indonesia masih mengimpor daging sapi sebab produksi dalam negeri belum bisa memenuhi kebutuhan dalam negeri. Maka pemerintah berupaya untuk meningkatkan hasil produksi dalam negeri salah satunya melalui Upaya 
Khusus Sapi Induk Wajib Bunting (UPSUS SIWAB) salah satu langkah dari upaya khusus tersebut adalah dalam penyediaan induk/bibit. Hal tersebut juga sudah diterapkan di Kabupaten Ciamis seperti penyediaan bibit unggulan dengan didirikannya balai pembibitan sapi pasundan/rancah. Pengembangan sapi pasundan/rancah saat ini sudah cukup berhasil dengan bertambahnya populasi sapi pasundan di Kabupaten Ciamis. Namun masyarakat khususnya peternak yang masih belum mengetahui peran dari komoditas unggulan tersebut sehingga peternak belum bisa mempertahankan sapi unggulan yang mereka pelihara karena tuntutan kebutuhan ekonomi yang akhirnya hanya ada satu kelompok peternak yang membudidayakan sapi pasundan. Saat ini peternak lebih tertarik untuk melalukan usaha penggemukan sapi potong karena waktu pemeliharaannya yang relatif lebih singkat. Sedangkan untuk peternak yang menjalankan usaha pembibitan sapi jarang sekali sehingga harus mendatangkan bakalan sapi dari luar daerah Kabupaten Ciamis, menurut Dinas Peternakan dan Perikanan Kabupaten Ciamis pemasok bakalan sapi berasal dari Jawa Timur dan Jawa Tengah. Oleh sebab itu, dalam pengembangan usaha sapi potong pemerintah perlu mempertahankan kebijakan-kebijakan yang sudah ada dan pengembangan sapi potong dapat lebih diarahkan pada usaha pembibitan sapi potong disamping usaha penggemukan sapi potong. Usaha pembibitan sapi potong mempunyai peluang pasar yang luas sebagai contoh bahwa Kabupaten Tasikmalaya dan Kota Tasikmalaya mendatangkan bakalan sapi potong dari luar daerahnya, sehingga Kabupaten Ciamis diharapkan kedepannya bisa menjadi pemasok bakalan sapi ke luar daerahnya.

Domba dan kambing dikategorikan sebagai komoditas prospektif di Kabupaten Ciamis, karena komoditaskomoditas tersebut disebagian besar kecamatan menjadi komoditas yang prospektif, berdaya saing namun memiliki pertumbuhan yang lambat. Maka dari itu agar komoditas-komoditas tersebut dapat menjadi komoditas unggulan, kedepannya perlu ada upaya untuk melakukan penambahan jumlah populasi baik domba maupun kambing kemudian diiringi dengan peningkatan pengetahuan peternak mengenai manajemen pemeliharaan yang baik sehingga dapat meningkatkan hasil produksinya. 
Ayam buras dapat dikategorikan sebagai komoditas prospektif, karena komoditas ayam buras disebagian besar kecamatan menjadi komoditas yang prospektif, berdaya saing namun memiliki pertumbuhan yang lambat. Meski bukan merupakan komoditas unggulan, akan tetapi ayam buras diperlukan untuk memenuhi kebutuhan di wilayah Kabupaten Ciamis maka usaha pengembangan komoditas ayam buras tetap diperlukan. Sedangkan menurut Dinas Peternakan dan Perikanan Kabupaten Ciamis (2020), komoditas ayam buras menjadi unggulan di Kabupaten Ciamis. Ayam buras yang sedang dikembangkan di Kabupaten Ciamis adalah ayam sentul.

Saat ini usaha ayam sentul masih menjadi usaha sampingan dengan skala kepemilikan yang kecil dan belum ada investor atau pengusaha yang tertarik terhadap usaha ternak ayam sentul. Masalah yang sering terjadi dalam budidaya ayam buras adalah wabah penyakit yang sering menyerang. Wabah penyakit yang sering menyerang adalah Newcastle Disease (NCD) atau penyakit tetelo. Kebanyakan peternak ayam tidak melakukan tindakan pencegahan terhadap wabah penyakit karena harga vaksin yang mahal tidak sebanding dengan keuntungan yang diperoleh karena jumlah ayam buras yang dipelihara sedikit sehingga menyebabkan kerugian bagi peternak ayam. Oleh sebab itu, perlu adanya peningkatan pengetahuan peternak mengenai manajemen pemeliharaan yang baik dan adanya penguatan kelembagaan peternak ayam buras, agar di kemudian hari ayam buras dapat menjadi komoditas yang unggulan dengan laju pertumbuhan yang cepat.

Ayam ras pedaging belum menjadi komoditas unggulan di Kabupaten Ciamis bahkan dikategorikan sebagai komoditas tertinggal, karena di sebagian besar kecamatan ayam ras pedaging menjadi komoditas yang tertinggal, memiliki pertumbuhan yang lambat meski memiliki daya saing. Meski bukan merupakan komoditas unggulan, akan tetapi ayam ras pedaging diperlukan untuk memenuhi kebutuhan di wilayah Kabupaten Ciamis, maka usaha pengembangan komoditas ayam ras pedaging tetap diperlukan. Menurut Dinas Peternakan dan Perikanan Kabupaten Ciamis (2020) bahwa komoditas ayam ras pedaging mendominasi usaha peternakan rakyat di Kabupaten Ciamis sehingga Kabupaten Ciamis menjadi sentra produksi ayam ras pedaging di Jawa Barat. Oleh sebab itu, 
kondisi ini perlu dipertahankan agar ke depannya Kabupaten Ciamis masih tetap menjadi sentra produksi ayam ras pedaging di Jawa Barat.

Ayam ras petelur menjadi komoditas unggulan di Kabupaten Ciamis, karena merupakan komoditas basis yang memiliki pertumbuhan yang cepat dan berdaya saing baik. Sedangkan menurut Dinas Peternakan dan Perikanan Kabupaten Ciamis (2020) komoditas ayam ras petelur bukan merupakan komoditas unggulan di Kabupaten Ciamis. Usaha ayam ras petelur masih didominasi oleh usaha peternak rakyat dengan skala kepemilikan yang kecil sehingga kurang efisien dibandingkan dengan pengusaha besar. Hal tersebut membuat peternaka rakyat kalah bersaing terutama dalam hal biaya produksi. Komponen biaya terbesar sekitar $60 \%$ dari total biaya produksi dalam usaha ayam ras petelur adalah biaya pakan. Selain itu juga keterbatasan modal yang menghambat peternak untuk meningkatkan skala usahanya, sehingga perlu adanya inovasi dalam pengolahan pakan dengan teknologi yang dapat meringankan beban biaya produksi.

Melihat permasalahan ini pemerintah Kabupaten Ciamis telah ikut bekerjasama dengan Bank Indonesia (BI) dalam rangka pembentukan klaster ayam ras petelur yang disahkan pada tahun 2019 di Desa Muktisari, Kecamatan Cipaku. Pembentukan klaster tersebut membantu peternak untuk memperoleh pembinaan baik secara teknik maupun secara modal, sehingga diharapkan permassalah yang ada dapat diselesaikan dan diharapkan para peternak akan lebih mandiri dan dapat meningkatkan pendapatan peternak. Oleh sebab itu, program ini dapat dipertahankan dan terus di tingkatkan agar dapat mencapai tujuan yaitu meningkatkan kesejahteraan peternak dan pada akhirnya dapat mengurangi jumlah pengangguran.

$\begin{array}{ccc}\text { Itik } & \text { berdasarkan } & \text { hasil } \\ \text { penggabungan } & \text { analisis LQ dan }\end{array}$
komponen pertumbuhan wilayah belum menjadi komoditas unggulan di Kabupaten Ciamis tetapi dikategorikan sebagai komoditas prospektif, karena disebagian besar kecamatan komoditas itik menjadi komoditas yang prospektif, memiliki daya saing namun memiliki pertumbuhan yang lambat. Sedangkan menurut Dinas Peternakan dan Perikanan Kabupaten Ciamis (2020), komoditas itik bukan merupakan komoditas unggulan. Meski demikian ternak itik masih dijadikan usaha ternak bagi sebagian masyarakat khususnya masyarakat di 
sekitar sentra pengembangan padi. Daerah sentra padi memiliki lahan sawah yang luas, lahan sawah setelah panen dapat dijadikan sebagai tempat berenang itik, guna untuk meningkatkan produktivitas telur. Selain itu, juga daerah sentra padi dapat menjadi sumber pakan bagi itik berupa dedak padi sehingga kebutuhan akan dapat terpenuhi dengan baik. Saat ini usaha ternak itik ditujukan untuk memenuhi kebutuhan telur sehingga kebanyakan peternakan mengusahakan itik petelur. Pangsa pasar telur itik yaitu tukang jamu dan industri telur asin.

Berdasarkan uraian di atas peran pemerintah daerah cukup baik dalam pengembangan komoditas-komoditas peternakan di Kabupaten Ciamis terutama pada komoditas peternakan yang sudah menjadi unggulan (sapi potong dan ayam ras petelur) pemerintah Kabupaten Ciamis perlu mempertahankan dan meningkatkan program-program yang ada agar dapat tetap menjadikan sapi potong dan ayam ras petelur menjadi komoditas unggulan. Sedangkan untuk komoditas peternakan yang belum menjadi unggulan yaitu komoditas prospektif (domba, kambing, ayam buras dan itik) dan komoditas tertinggal (ayam ras pedaging) masih perlu perhatian yang lebih khususnya dalam peningkatan kualitas Sumber Daya Manusia (SDM) yang masih rendah. Salah satu caranya dengan adanya pemberdayaan bagi peternak. Menurut Harry Hikmah dalam Dwiko Septiadi Rusadi (2013) bahwa kegiatan pemberdayaan peternak merupakan upaya mengubah kesadaran, memperkuat keinginan dan perlakuan masyarakat sebagai pelaku yang berperan dalam peningkatan produksi peternakan ${ }^{1}$.

$$
\text { Kemudian Sukirno }
$$
menerangkan bahwa salah satu strategi pemberdayaan petani/peternak ialah melalui pendidikan dan pelatihan baik melalui pendidikan formal maupun non formal. Pendidikan formal yaitu mulai dari pendidikan TK (Taman Kanakkanak) sampai dengan perguruan tinggi. Pendidikan ini memberikan pengetahuan dasar dalam pengembangan pengetahuan lain yang dapat dimanfaatkan dalam kehidupan sehari-hari baik sektor formal maupun in formal. Sedangkan pendidikan non formal yaitu dapat ditempuh melalui pelatihan untuk mengembangkan pengetahuan, keterampilan dan sikap

\footnotetext{
${ }^{2}$ Dwiko Septiadi Rusadi, Pemberdayaan Petani Peternak Melalui Kelompok Usaha Bersama Agribisnis, diakses dari "http://dwikoseptiyadir.blogspot.com/2013/02/pe mberdayaan-petani-peternak-melalui.html? $\mathrm{m}=1$ " (diakses 06 September 2020)
} 
dalam bekerja untuk mengembangkan usahanya. Pendidikan tersebut dapat ditempuh melalui peningkatan kegiatan penyuluhan dan pelatihan keterampilan usaha bagi peternak.

Kegiatan penyuluhan untuk saat ini dapat ditekankan pada peningkatan pengetahuan mengenai manajemen pemeliharaan ternak guna mendorong peningkatan produksi peternakan. Manajemen pemeliharaan yang baik menurut Suyatno (1983) dalam Mitra Agro Sejati dimulai dari persiapan perkandang dan peralatan, pemeliharaan, pemberian pakan, pencegahan dan pemberantasan penyakit dan pengelolaan pascapanen. Peternak dalam penyiapan kandang dan peralatan sudah cukup baik, akan tetapi dalam hal pemberian pakan yang masih belum sesuai dengan kebutuhan gizi ternak sehingga pemberian pakan belum efektif yang menyebabkan hasil produksi ternak tidak optimum. Selain itu, juga perlu adanya teknologi baru dalam penyusunan pakan ternak atau ransum yang lebih murah dengan memanfaatkan sumber daya lokal. Sebagaimana diketahui bahwa pakan ternak khususnya untuk ayam ras masih impor sehingga biaya produksi untuk pakan merupakan komponen biaya terbesar dalam usaha ini. Adanya pengurangan penggunaan bahan baku pakan impor dengan lebih banyak memanfaatkan sumber pakan lokan dapat mengurangi tingginya biaya produksi.

Kemudian permasalah pencegahan dan pemberantasan penyakit yang masih kurang karena harga vaksin yang cukup mahal tidak sebanding dengan keuntungan yang diperoleh karena peternak melakukan usaha ini hanya sebagai sampingan belum bertujuan untuk komersil sehingga skala kepemilikan ternak pun kecil. Oleh sebab itu, melalui pemberdayaan masyarakat petani peternak melalui pendidikan non formal sebagaimana diuraikan sebelumnya diharapkan mampu lebih meningkatkan kualitas dari sumber daya manusia di sub sektor peternakan khususnya di bagian on farm. Kemudian ke depannya dengan adanya peningkatan kualitas sumber daya manuasia dapat mampu meningkatkan kesejahteraan pelaku utama dan pelaku usaha dalam sub sektor peternakan ini.

\section{KESIMPULAN DAN SARAN}

\section{Kesimpulan}

Berdasarkan hasil penelitian dan pembahasan dapat diambil kesimpulan sebagai berikut: 
1. Komoditas peternakan basis di wilayah kecamatan Kabupaten Ciamis adalah ternak sapi, domba, kambing, ayam buras, ayam ras pedaging, ayam ras petelur dan itik.

2. Pertumbuhan komoditas peternakan basis di wilayah kecamatan Kabupaten Ciamis yang mengalami pertumbuhan cepat adalah ternak sapi potong dan ternak ayam ras petelur, dan komoditas peternakan basis yang berdaya saing baik adalah ternak sapi potong, kambing, ayam buras, ayam ras pedaging, ayam ras petelur dan itik.

3. Komoditas peternakan yang menjadi komoditas unggulan di Kabupaten Ciamis adalah sapi potong dan ayam ras petelur.

\section{Saran}

Berdasarkan hasil penelitian maka saran yang dapat disampaikan adalah sebagai berikut:

1. Pemerintah daerah diharapkan dapat mempertahankan kebijakan-kebijakan dan program-program yang sedang dijalankan, dimana program-program tersebut dapat mendorong komoditas peternakan yang menjadi unggulan (sapi potong dan ayam ras petelur) tetap menjadi komoditas unggulan.
2. Adanya peningkatan kualitas Sumber Daya Manusia (SDM) khususnya peternak dengan mendorong dan memfasilitasi masyarakat untuk memperoleh pendidikan baik formal maupun informal (peningkatan kegiatan penyuluhan) sehingga pengelolaan potensi peternakan di Kabupaten Ciamis lebih optimal.

3. Perlu adanya penelitian lebih lanjut mengenai daya dukung dan kapasitas tampung wilayah yang menjadi wilayah pengembangan komoditas peternakan unggulan dengan menghitung Indek Daya Dukung (IDD) sehingga dapat diketahui ketersediaan dan daya dukung pakan ternak yang dapat dipenuhi oleh wilayah pengembangan komoditas peternakan unggulan.

\section{DAFTAR PUSTAKA}

A. Chaedar Alwasilah. (2015). Pokoknya Studi Kasus Pendekatan Kualitatif. Bandung: PT Kiblat Buku Utama. Ipusnas.

Andi Posman Simamora, Sirojuzilam dan Supriadi. (2013). Analisis Potensi Sektor Pertanian Terhadap Pengembangan Wilayah Di Kabupaten Humbang Hasundutan. Jurnal Ekonomi, IVX(2): 54-66.

Arief Daryanto dan Yundy Hafizrianda. (2010). Model-Model Kuantitatif Untuk Perencanaan Pembangunan Ekonomi Daerah: Konsep dan 
Aplikasi. Kampus IPB Kencana Bogor: IPB Press. Ipusnas.

Badan Perencanaan Pembangunan Daerah Kabupaten Ciamis. (2019). Rancangan Peraturan Daerah Kabupaten Ciamis No Tahun 2019 Tentang Rencana Pembangunan Jangka Menengah Daerah Kabupaten Ciamis Tahun 2019$2024 . \quad$ Tersedia: http://bappeda.jabarprov.go.id.

Badan Pusat Statistik Kabupaten Ciamis. (2018). Produk Domestik Regional Bruto Kabupaten Ciamis Menurut Lapangan Usaha Tahun 20142018 .

Tersedia:

https://ciamiskab.bps.go.id. . (2019). Kabupaten Ciamis dalam Angka Tahun 2019. Tersedia: https://ciamiskab.bps.go.id.

Bambang Agus Murtidjo. (1993). Memelihara Kambing Sebagai Ternak Potong Dan Perah. Yogyakarta: Kanisius .

Chris Dian F. (2013). Cara Sukses Memulai dan Menjalankan Usaha ternak Domba. Jogjakarta: Trans Idea Publishing.

Christea Frisdiantara dan Imam Mukhlis. (2016). Ekonomi Pembangunan Sebuah Kajian Teoritis dan Empiris. Malang: Universitas Kanjuruhan. Ipusnas.

Dewi Karina Yuda dan Prananda Navitas. (2014). Arahan Pengembangan Ekonomi Kabupaten Lamongan Berdasarkan Sektor Unggulan (Studi Kasus: Sektor Pertanian). Jurnal Teknik Pomits, III(2): 136141.

Dinas Pertanian Kabupaten Ciamis. (2020). Luas Panen Tanaman Padi, Jagung dan Kedelai Tiap Kecamatan di Kabupaten Ciamis Tahun 2018. Tidak dipublikasikan.

Dinas Peternakan dan Perikanan Kabupaten Ciamis. (2019). Produksi Peternakan Tiap
Kecamatan di Kabupaten Ciamis Tahun 2013 - 2018. Tidak dipublikasikan. . (2020). Rencana Strategis Dinas Peternakan dan Perikanan Kabupaten Ciamis Tahun 2019 2024. Tidak dipublikasikan.

Djoko Sudantoko. (2003). Dilema Otonomi Daerah. Yogyakarta: Penerbit Andi. Ipusnas.

DS Priyarsono, Sahara, dan M Firdaus. (2016). "Analisis Shift Share". Dalam Materi Pokok Ekonomi Regional, diedit oleh Endang $\mathrm{R}$ Palupi, 7.2 - 7.31. Tangerang Selatan: Universitas Terbuka.

Dwi Septiadi Rusadi. (2013). Pemberdayaan Petani Peternak Melalui Kelompok Usaha Bersama Agribisnis.

http://dwikoseptiyadir.blogspot.co $\mathrm{m} / 2013 / 02 /$ pemberdayaan-petanipeternak-melalui.html? $\mathrm{m}=1$. Diakses pada 06 September 2020.

Ema Suhaeman, Widiatmaka dan Boedi Tjahjono. (2014). Pengembangan Wilayah Peternakan Sapi Potong Berbasis Kesesuaian Fisik Lingkungan dan Kesesuaian Lahan untuk Pakan di Kabupaten Cianjur. Jurnal Tanah Lingkungan, IVX(2): 53-60.

Emil Salim. (2013). Sukses Bisnis dan Beternak Sapi Potong. Yogyakarta: Lyli Publisher.

Ernan Rustiadi, Sunsun Saefulhakim, dan Dyah R. Panuju. (2011). Perencanaan Dan Pengembangan Wilayah. Jakarta: Yayasan Pustaka Obor Indonesia. Diakses dari Ipusnas.

Fredinata Charles, Adi Suyatno dan Hamid A. Yusra. (2018). Penentuan Komoditas Unggulan Sektor Pertanian di Kabupaten Landak. Jurnal Agribisnis 2018.

Hajeri, Erlinda Yurisinthae dan Eva Dolorosa. (2015). Analisis 
Penentuan Sektor Unggulan Perekonomian di Kabupaten Kubu Raya. Jurnal Ekonomi Bisnis dan Kewirausahaan, IV(2): 253-269.

Hanny Siagian. (2011). Kontribusi Usaha Peternakan Dalam Pengembangan Wilayah. Jurnal Wira Ekonomi Mikroskil, I(1): 31-35.

H. Rahmat Rukmana. (2010). Beternak Domba. Semarang: CV Aneka Ilmu. Ipusnas.

Kementerian Pertanian Direktorat Jenderal Peternakan dan Kesehatan Hewan. (2018). Statistik Peternakan dan Kesehatan Hewan 2018. Tersedia: http:// Ditjennak.pertanian.go.id.

Kumparan. (2018). Benarkah Ikan Lebih Sehat Dibanding Jenis Daging Lainnya.

https://www.google.com/amp/s/m.k umparan.com/amp/kumparanfood/b enarkah-ikan-lebih-sehat-

dibanding-jenis-daging-lainnya1539938251448722498. Diakses pada 12 Maret 2020.

Maman Surachman. (2018). Peluang Usaha Ternak Bebek Secara Intensif. Jakarta: Indocamp.

Mitra Agro Sejati. (2017). Budi Daya Ayam Broiler. CV Pustaka Bengawan. Ipusnas.

Moch Sulistyo Kurniawan, Sudarti dan Zainal Arifin. (2017). Analisis Potensi Struktur Ekonomi Unggulan Dan Daya Saing Sub Sektor Pertanian Di Kota Batu Tahun 2011-2015. Jurnal Ekonomi, I(4): 416-429.

Mudrajad Kuncoro. (2018). Perencanaan Pembangunan Daerah: Teori dan Aplikasi. Jakarta: PT Gramedia Pustaka Utama. Ipusnas.

Muhammad Rasyaf. (2011). Beternak Ayam Kampung. Jakarta: Penebar Swadaya Group

Purnawan Yulianto dan Cahyo Saparinto. (2010). Pembesaran Sapi Potong
Secara Intensif. Jakarta: Penebar Swadaya.

Robinson Tarigan. (2005). Ekonomi Regional Teori dan Aplikasi. Jakarta: Bumi Aksara.

Sjafrizal. (2014). Perencanaan Pembangunan Daerah Dalam Era Otonomi. Jakarta: PT Raja Grafindo Persada.

Sudarti. (2009). Penentuan Leading Sektor Pembangunan Daerah Kabupaten/Kota di Jawa Timur. Jurnal Humanity Vol. V No. 1: 68 79.

Sukino. (2013). Membangun Pertanian Dengan Pemberdayaan Masyarakat Tani. Yogyakarta: Pustaka Baru Press.

Suyatno. (2000). Analisis Economic Base Terhadap Pertumbuhan Ekonomi Daerah Tingkat II Wonogiri: Menghadapi Implementasi UU No. 22/1999 dan UU No. 5/1999. Jurnal Ekonomi Pembangunan, I(2): 144-159.

Undang-Undang No. 33 Tahun 2004 tentang Pemerintah Daerah.

Wheindrata HS. (2013). A to Z Rahasia Beternak Bebek Petelur Unggulan. Yogyakarta: Lily Publisher .

Wulandari. (2008). Pembangunan Wilayah Kecamatan Berbasis Komoditas Pertanian Di Kabupaten Kudus (Pendekatan Location Quonteint dan Shift Share). Skripsi. Jurusan Sosial Ekonomi/Agrobisnis Fakultas Pertanian Universitas Sebelas Maret.

Zainal Abidin. (2018). Identifikasi Komoditas Unggulan Wilayah dalam Perspektif Pertanian Berkelanjutan di Sulawesi Selatan Tenggara. Jurnal Mega Aktiva, VII(2): 92-105. 